\title{
THE CRIMEAN WAR: A CLASH OF CIVILIZATIONS
}

\author{
Tatyana V. Vakulova \\ Sevastopol State University, Sevastopol, Republic of Crimea, Russian Federation
}

\begin{abstract}
The need to use the civilizational approach to the analysis of the causes and outcomes of the Crimean war (campaign) 1854-1855 is revealed in this article.

The author analyzes the causes of the war related to the religious factor. The Soviet historiography had not considered the religious factor to be relevant for the progressive development of the state, and therefore the provisions of the mentioned approach had not been used in the analysis of historical events. The conflict that arose between France and Russia about the Holy places, is characterized by the fact that the keys of the Bethlehem Church had been taken from the Orthodox community, which they traditionally belonged to, and had been handed over to the Catholic community by the Turkish authorities of Palestine under France's constraint.

The author points to the main cause of the war - violation of the Russian law on the protection of Orthodoxy in Turkey fixed by international treaties. It is argued that it is natural to name this war - The battle for the Manger of the Lord. That is why the main events of inter-civilizational conflict took place in the Crimea and in Sevastopol, which had not only been the military base of Russia on the Black Sea, but also the cradle of Russian Orthodoxy.

Analyzing the events, the author comes to the conclusion that the outcome of the war testifies to the victory of the Orthodox state and the Russian diplomacy, because the status quo of the Holy places was maintained in accordance with the state of Affairs which had existed in the Byzantine Empire.

The preservation of the integrity and sovereignty of Orthodox state is the confirmation of this victory. It is shown the ability to evaluate the results of the war is based on the positions of a civilizational approach.

Key words: civilizational approach, European civilization, Orthodox-Slavic civilization, the Crimean war, intercivilizational war, a clash of civilizations.
\end{abstract}

УДК 327.26

Дата поступления статьи: 22.06.2016

ББК 66.4 Дата принятия статьи: 23.09.2016

\section{КРЫМСКАЯ ВОЙНА: КОНФЛИКТ ЦИВИЛИЗАЦИЙ}

\section{Татьяна Владимировна Вакулова}

Севастопольский государственный университет, г. Севастополь, Республика Крым, Российская Федерация

Аннотация. Раскрывается необходимость использования цивилизационного подхода для анализа причин и итогов Крымской кампании 1854-1855 годов. На основании положений теории рассматриваются причины войны, связанные с религиозным фактором. Советская историография не рассматривала религиозную проблематику как значимую в прогрессивном развитии государства, поэтому не использовались положения данной теории для анализа исторических событий. Рассматривается конфликт, возникший между Францией и Россией о святых местах, характеризующийся тем, что ключи от Вифлеемского храма были отобраны у православной общины, которой они традиционно принадлежали, и под давлением Франции переданы турецкими властями Палестины католической общине. Указывается на главную причину войны - нарушение закрепленного международными договорами права России на покровительство православия в Турции. Утверждается, ч что закономерным является и другое название этой войны - «битва за Ясли Господни». Именно поэтому ‥ главные события этого межцивилизационного конфликта происходили в Крыму и Севастополе, который являл๘ ся не только военной базой России на Черном море, но и колыбелью русского православия.

Анализируя события, автор приходит к выводу, что итоги войны свидетельствуют о победе православного государства и русской дипломатии, так как был сохранен статус-кво святых мест в результате бескомп(?) ромиссной позиции России в деле защиты прав Иерусалимской Православной Церкви в Палестине в соот- 
ветствии с положением дел, существовавшим со времен Византийской империи. Подтверждением победы является Договор о запрете на пребывание в Черном море военных кораблей не только России и Турции, но и любых других стран, при этом Российская империя сохранила свою целостность и суверенитет. Анализ причин и итогов противостояния европейской и православно-славянской цивилизаций сквозь призму цивилизационного подхода показал возможность оценивать результаты войны исходя из позиций цивилизационного подхода.

Ключевые слова: цивилизационный подход, европейская цивилизация, православно-славянская цивилизация, Крымская война, межцивилизационная война, конфликт цивилизаций.

С позиций цивилизационного подхода Крымскую войну можно рассматривать как войну межцивилизационную, между западной (католической) и славянской (православной) цивилизациями. В этой войне наиболее ярко проявились истинные цели и отношение западной цивилизации к православно-славянской. Крымская война носила общеевропейский характер, именно в ней очевидным было европейское единство против России, соперничество двух цивилизаций. В Крымской войне опасность для России исходила от любой страны европейской цивилизации. Этот факт не давал возможности использовать больше военных сил в Крымской кампании, так как они были задействованы по всем границам империи. Считается, что если бы под Севастополь была направлена кавказская армия, исход войны мог быть другим.

Причины Крымской войны иногда связывают с «восточным вопросом». Но это не вполне так, главным в ней, на наш взгляд, был вопрос не о разделе османских владений, а о гегемонии в Европе. Известно, что одним из поводов для Восточной войны стал государственный переворот во Франции в декабре 1851 года. Племянник Наполеона I Луи-Наполеон провозгласил себя императором Наполеоном III, нарушив при этом не только законы французского государства, но и международный договор, который запрещал представителям семьи Наполеона занимать французский престол [3, с. 342]. Европейские государства не реагировали на это нарушение в отличие от России, где Николай I, соблюдая международное соглашение, отказался признавать самозванца императором. Ольмюцкое решение так же не вызвало противодействия со стороны Запада, оно было поддержано европейскими политиками.

Нужно отметить, что в период до 1853 г. во взаимодействии между европейской и сла- вянской цивилизациями российская дипломатия лидировала. Впоследствии английский министр Кларендон заявил в парламентском выступлении, что в те времена, по общему мнению, Россия обладала не только «подавляющей военной силой», но и дипломатией, отличающейся «несравненной ловкостью» [7].

Мощь России во главе с Николаем I после венгерской кампании и после Ольмюца была непобедимой. В 1851 г. барон Штокмар, друг принца Альберта и английской королевы Виктории, в связи с этим писал: «Когда я был молод, то над континентом Европы владычествовал Наполеон. Теперь дело выглядит так, что место Наполеона занял русский император, и что, по крайней мере в течение нескольких лет, он, с иными намерениями и иными средствами, будет диктовать законы континенту» [7].

Можно утверждать, что к началу 50-х гг. XIX в. Российская империя достигла могущества в межцивилизационном противостоянии. При этом противоречия внутри европейской цивилизации между Англией и Францией существовали, но отходили на второй план перед объединяющей борьбой против России. «Не случайно лорд Г.Д. Пальмерстон приветствовал государственный переворот Наполеона III, его расчет заключался в том, что он увидел в Наполеоне III орудие антирусской политики Англии» [12, с. 127-128].

Таким образом, не столько в русской угрозе, а в стремлении западной цивилизации контролировать и противостоять России заключались мотивы Крымской войны. Б. Елавич, американский историк, писала, что после наполеоновских войн Россия была единственной страной Европы, не имеющей претензий ни к одному из своих соседей. Не России, а ведущим западноевропейским странам, прежде всего Англии, было необходимо разрушение сложившейся системы международных 


\section{ОТЕЧЕСТВЕННАЯ ИСТОРИЯ}

отношений, для осуществления чего выдвигалась военная программа [6, с. 39].

Наполеон III понимал, что его власть не воспринимается как легитимная, и поэтому уже в 1852 г. в Европе складываются контуры антироссийской коалиции. Для отвлечения европейской общественности от обсуждения государственного переворота во Франции использовали ситуацию на Востоке, где на территории Османской империи православные и католики совершали паломничество к святым местам. Здесь Россия покровительствовала православным, а Франция - католикам. Споры между конфессиями относительно привилегий и прав верующих разрешались на переговорах с Портой. Используя религиозные споры, Наполеон III заявил о преимуществах католиков по сравнению с православными. Его цель была пойти на конфликт с Россией и под религиозным предлогом получить возможность усилить свое влияние на Ближнем Востоке.

Николай I отправил в Стамбул посольство во главе с А.С. Меншиковым, который прославился в войнах против Наполеона, в турецкой войне 1828 г., а в войне 1853-1856 гг. командовал русской армией в Крыму. Как известно, Альминское сражение не принесло победы и славы А.С. Меньшикову, но тогда он направился в Стамбул с дипломатической миссией. Параллельно шли тайные переговоры России и Англии относительно раздела Турции.

Николай I предложил англичанам Египет и Крит, но они отвергли это предложение. Более того, английский посол Стретфорд де Редклиф прибыл в Стамбул и противодействовал Меншикову, он тайно сговорился с французским послом Эдмондом де Лакуром, и они вели общую антироссийскую борьбу. Меншиков предъявил ультиматум: либо признать за православной церковью не только религиозные, но и светские привилегии, либо переговоры прекращаются. Султан отклонил ультиматум, поэтому 21 июня 1853 г. русская армия перешла границу Турции, а 4 июля 1853 г. вступила в пределы Дунайских княжеств. Переговоры продолжились, и была выработана «Венская нота». Австрия стремилась к тому, чтобы стороны приняли Венскую ноту, при этом Вена гарантирует Стам- булу, что русский царь не намерен в дальнейшем увеличивать свои притязания. Турция с помощью Англии и Франции готовилась к войне и не согласилась с этой инициативой, и 4 октября 1853 г. султан объявил войну России $[13$, с. 63$]$.

Считается, что Россия по нескольким причинам проиграла Крымскую войну. Знаменитое ленинское «Крымская война показала гнилость и бессилие крепостной России» [9], или, например, Е.В. Тарле, описывая агрессивные планы западных государств и России на Ближнем Востоке, отмечает, что дипломатическая борьба закончилась для Англии и Франции победой, а для России поражением: «Царизм начал и он же проиграл эту войну, обнаружив... несостоятельность... господства дворянско-феодального крепостнического строя» $[13$, c. 5$]$.

Первая причина поражения политическая - государства западной цивилизации Англия и Франция объединились против России в межцивилизационном противостоянии. Европа запомнила победу России после поражения Наполеона в 1812-1814 гг. и боялась повторить свою ошибку. Вторая причина социально-экономическая. В России сохранялось крепостное право, а это ограничивало развитие промышленности. Третья причина - военно-техническая, согласно которой армия России не была вооружена по новейшим военным технологиям того времени и во многом уступала западным странам. Русские войска были более уязвимы, сомкнутый строй русской армии был рассчитан на штыковую атаку, а у французов действовал принцип «нарезные штуцера», когда строй егерей «врассыпную» атаковал русские войска. Стоит отметить, что в России уже знали нарезное оружие (штуцеры), но по количеству оно уступало французам и англичанам. В этих условиях Россия воевала против пяти государств на трех фронтах.

Боевые действия Крымской войны велись в Крыму, на Дунае и на Кавказе. Кавказскую кампанию Россия выиграла, при этом турки потерпели поражение. Важно, что инициатором мирных переговоров выступила Франция, а не Россия. Очевидно, что главная причина поражения - политические просчеты России. Англия стремилась в Крым и на Кав- 
каз, здесь столкнулись интересы России, Англии и Франции. Царь надеялся, что Англия будет его союзником, надеялся на поддержку Пруссии, где правил брат его жены, но Фридрих Вильгельм, король Пруссии, сохранил враждебный нейтралитет.

Возникает вопрос, можно ли борьбу за «турецкое наследство» определить как межцивилизационный конфликт? Как религиозное противостояние православия, католичества, протестантизма и ислама отразилось при решении «восточного вопроса»? Почему в Крымской войне ведущие европейские страны выступали против России, либо сочувствовали ей, но никто ее не поддержал?

Интересно, что эти вопросы волновали русских мыслителей еще в годы Крымской войны 1854-1855 годов. Именно идея цивилизационного конфликта приобретает особую актуальность в отечественной философской мысли данного периода, и этот факт имеет большое значение, потому что это была попытка уже тогда, в середине XIX в., охарактеризовать Крымскую войну, применяя цивилизационный подход, как конфликт цивилизаций. Ф.М. Достоевский, указывая в качестве причины войны на столкновение цивилизаций, писал, что Запад потерял веру, погряз в алчности с его идеей всеобщего братства и единения [4, с. 47].

Отечественная мысль о соперничестве цивилизаций оформляется уже во второй половине XIX - первой четверти XX века. В России было сформировано научное направление, изучавшее локальные цивилизации, в рамках которого вырабатывалось представление о войне не только как о социально-политическом явлении, но и как о конфликте культур, конфликте цивилизаций.

Яркими представителями этого направления были А. Хомяков, Н. Данилевский, Вл. Соловьев, С. Булгаков, В. Эрн, Е. Трубецкой, Н. Бердяев [8, с. 40-41]. Они с цивилизационной, культурно-духовной позиции показали роль войны в конкретных столкновениях цивилизаций. Источником таких воззрений на данную тематику были традиции русской общественной мысли о судьбе России в русле ее мессианского предназначения в мировой истории и культуpe, в разрешении спора между восточной (православной) и западноевропейской цивилизаци- ями. Провиденциальное понимание истории мыслители связывали с провидением. Оправдание межцивилизационной войны носило у них духовно-нравственную окраску [2, с. 52].

Русские мыслители, а затем и западные считали, что ход исторического процесса представляет собой постепенное осуществление истины христианства, а смысл истории заключается в достижении «Царства Божия на земле», то есть создании совершенного общества [8, с. 45]. А. Хомяков писал, что политические, экономические и природные факторы в истории подчинены духовно-культурному началу, сформулировал главный признак принадлежности к цивилизации - принадлежность к какой-либо религии $[14$, с. 6$]$. И именно это убеждение впоследствии дало возможность с позиций христианской веры обосновать концепцию смысла войны в развитии православной цивилизации и всей мировой культуры. Основные различия линий исторического развития России и Запада заключены во внутренних началах этих цивилизаций - в православной и католической религиях.

А. Хомяков видел решающую роль России в цивилизационном противостоянии, за сохранение православной религии и церкви, потому что считал, что «третий Рим» является выразителем истинного (православного, а не искаженного - католического) христианского учения, и в этом заключается историческая миссия России в мировой истории, за это она воюет и побеждает в войнах. Русские философы видели в России носительницу мессианской идеи, они сформулировали «русскую идею» - идею богоизбранности и величия России $[1$, с. 253].

С началом Крымской войны мессианские настроения приобрели новое еще более сильное значение, стали подниматься патриотические настроения, на Крымскую войну возлагалась надежда реализации «русской идеи» - сохранения и распространения православия, война рассматривалась как средство выполнения «вековой задачи русской истории», которая признавалась оправданной и законной [6, c. 52].

Именно цивилизационная теория служит основой для переосмысления существующих взглядов на причины, повод, характер и итоги войны. 


\section{ОТЕЧЕСТВЕННАЯ ИСТОРИЯ}

В общественном сознании опровергался миф о Крымской войне как о войне, в которой Россия потерпела поражение, так как была отсталым государством. Это не так, во-первых, потому, что еще со времен Петра I и до Николая II Россия вела десять войн с турками, а Крымская война была восьмой по счету. Могло ли отсталое государство вести столько войн? Вряд ли.

Во-вторых, когда Турция объявляла войну России, она была мощной державой, имела огромные пространства Османской империи, занимала земли нынешней Турции, Ирака, Сирии, Кувейта, стран Аравийского полуострова, Египта, Ливии, Туниса, территории, где жили христиане, находившиеся под влиянием исламской цивилизации.

В-третьих, союзниками Османской империи выступали государства западной цивилизации, Британская империя и Франция. Кроме этих врагов, России противостояли империя Габсбургов и королевство Пруссия. Этот факт вынуждал русское командование держать очень крупные войска на западных границах России, вместо того, чтобы перебросить их в Крым, под Севастополь. Можно ли говорить о слабой России? Точнее будет сказать о мощной антироссийской коалиции, против которой вряд ли кто-то мог устоять. Очевидной является идея, высказанная С.Г. Киселевым о том, что западная цивилизация в Крымской войне сталкивала Россию и исламскую цивилизацию [8, с. 222].

Принято считать, что Русский флот не отвечал требованиям того времени. Однако в 1828-1829 гг. Россия вела морскую войну с Турцией - в то время первоклассной морской державой - и выиграла ее, разгромив турецкий флот в Черном море. Только две страны мира имели паровой военный флот, но это не означает отставания России от других стран мира. В России понимали необходимость парового военного флота и занимались его развитием. Единственное, чему не мог противостоять русский флот, это объединенная сила английского и французского флотов. Поэтому, миф об отставании России в период Крымской войны был мнимым [10].

Все воюющие государства имели свои интересы в Восточном конфликте. Россия добивалась выхода из Черного моря для уси- ления своих позиций на Ближнем Востоке и Балканах. Османская империя хотела вернуть территории, потерянные в ходе русско-турецких войн. Англия и Франция надеялась сокрушить Россию как великую державу, лишить ее влияния на Ближнем Востоке и Балканском полуострове.

Российский ученый-востоковед В.И. Шеремет считает, что Восточную войну начал Ватикан, решив бороться против стремительного усиления восточно-христианского мира. В своих выводах он опирается на хранящиеся в российских архивах уникальные арабские, турецкие, курдские документы, показания пленных, данные разведки. Историк также сообщил, что в архиве внешней политики Российской империи (АВПРИ МИД России) обнаружены нетронутые ранее секретные документы, проливающие свет на конфликт между папой Пием IX и Наполеоном III - c одной стороны, и православным духовенством Иерусалимской Церкви и императором Николаем I - с другой [15].

Обращение к цивилизационной теории, в основе которой лежат духовные составляющие цивилизации - религия, язык и культура, как видим, открывает новые факты и точки зрения на Крымскую войну. Это была война не столько «за корыстные интересы царизма», a «священная война» за христианские святыни, за ключи от храма Гроба Господня и Вифлеемского храма. Это «война против притеснения православных общин Иерусалима и Востока» [15].

Что касается итогов Крымской кампании, то исследователь М.М. Якушев пишет: «статус-кво святых мест был сохранен кровью русских солдат - в результате бескомпромиссной позиции России в деле защиты преимущественных прав Иерусалимской Православной Церкви в Палестине в соответствии с положением дел, существующим со времен Византийской империи» [15]. Цель, которую преследовала православная Россия, объявляя войну мусульманской Османской империи, сохранение статуса святых мест - была ею полностью достигнута.

Подтвердил этот факт Парижский мирный договор от 30 марта 1856 года. Договор явился победой русской дипломатии Александра II. Лишившаяся Черноморского флота 
Россия все же добилась запрета на пребывание в Черном море военных кораблей не только Турции, но и любых других стран. Империя сохранила свою целостность и суверенитет.

14 июля Александр II учредил в Таврической губернии, как свидетельство победы духа над материальным злом, Космо-Дамиановский монастырь на чудотворном источнике. Учреждение монастыря - вполне естественная форма ознаменования финала для войны, которую современники называли «битвой за Ясли Господни» [5]. Севастополь стал оплотом православной цивилизации в Крымской войне, именно Севастополь дал миру пример героической жизни и смерти.

Западная коалиция ведущих мировых индустриальных держав и исламского государства, превосходившая по силе Россию, не смогла изменить геополитическое пространство Евразии в данной войне. Хотя на юге в ходе обороны Севастополя Россия потерпела неудачу, зато на Кавказе русская армия выиграла все сражения с турками, заставила капитулировать защитников крепости Карс. Военные успехи позволили России впоследствии обменять обширные территории в Малой Азии на морскую крепость Севастополь, которую современники назвали «новой Троей» [5].

Благодаря цивилизационной теории становится более очевидным, что в Крымской войне огромную роль играла именно религиозная, духовная составляющая, межцивилизационное взаимодействие имело сакральный смысл, а война рассматривалась не только как политическая, но священная. Для России вопрос веры оказался с политической точки зрения гораздо более важным, чем вопрос о территориях, которые на время пришлось оставить. В итоге по договору Россия вернула себе Севастополь и другие города в обмен на крепость Каре, уже в 1870-1871 гг. отказалась признавать статьи Парижского мирного договора, запрещавшие ей иметь на Черном море военный флот, и западные державы вынуждены были это признать.

Война не была проиграна, потому что ее цель с точки зрения цивилизационного подхода - сохранение своих прав к святым местам в Палестине была выполнена, права Иерусалимской Православной Церкви были сохранены и закреплены международным многосто- ронним договором. Россия реализовала собственные задачи и выстояла в конфликте с Европой, не допустила своего расчленения, в целом сохранила российские территориальные пределы и геополитическую ситуацию в мире.

\section{СПИСОК ЛИТЕРАТУРЫ}

1. Вакулова, Т. В. Конфликт цивилизаций как проблема русской философии XIX-XX веков / Т. В. Вакулова // Ученые записки Таврического национального университета им. В.И. Вернадского. Серия «Философия. Социология». - 2008. T. 21 (60), № 3. - C. 249-260.

2. Вакулова, Т. В. Политологический анализ Крымской войны через призму цивилизационной теории / Т. В. Вакулова // Город славы и поклонения : материалы науч.-практ. конф. - Севастополь, 2008. - C. 50-59.

3. Дебидур, А. Дипломатическая история Европы. Священный Союз от Венского до Берлинского конгресса. 1814-1878. Т. 1 / А. Дебидур. - Ростов н/Д : Феникс, 1995. - 508 с.

4. Достоевский, Ф. М. Парадоксалист / Ф. М. Достоевский // Русские философы о войне: Ф. М. Достоевский, Вл. Соловьев, Н. А. Бердяев, С. Н. Булгаков, Е. Н. Трубецкой, С. Л. Франк, В. Ф. Эрн. - М. : Кучково поле, 2005. - 496 с.

5. Дубровин, Н. Ф. Первая оборона Севастополя 1854-1855 гг. «Русская Троя» / Н. Ф. Дубровин. - М. : Эксмо : Яуза, 2014. -478 с.

6. Елавич, Б. Россия и осложнения на Балканах. 1806-1914 / Б. Елавич. - Кембридж : Газета Кембридж. ун-та, 1991. - 292 с.

7. История дипломатии. Библиотека внешней политики. В3 т. / под ред. В. П. Потемкина. - М. : ОГИЗ. Соцэкгиз, 1941-1945. - 1873 с. - Электрон. текстовые дан. - Режим доступа: http://www.nnre.ru/istorija/ tom_1_istorija_diplomatii index.php. - Загл. с экрана.

8. Киселев, С. Г. Основной инстинкт цивилизаций и геополитические вызовы России / С. Г. Киселев. - М. : Известия, 2002. - 368 с.

9. Ленин, В. И. «Крестьянская реформа» и пролетарски-крестьянская революция / В. И. Ленин // Полное собрание сочинений : в 55 т. - 5-е изд. М. : Изд-во полит. лит., 1973. - Т. 20. - С. 173.

10. Мифы Крымской войны. - Электрон. текстовые дан. - Режим доступа: http://www.rne.org/sfk/ 0401/0401-16.shtml (дата обращения: 30.05.2016). Загл. с экрана.

11. Селищев, Н. Ю. Крымская война: миф об отсталой России / Н. Ю. Селищев // Русский Вестник. - 2004. - 29 июня. - Электрон. текстовые дан. Режим доступа: http://rusk.ru/st.php?idar=318133 (дата обращения: 03.11.2016). - Загл. с экрана. 
12. Татищев, С. С. Внешняя политика императора Николая Первого. Введение в историю внешних сношений России в эпоху Севастопольской войны / С. С. Татищев. - СПб. : Тип. И.Н. Скороходова, 1887. $-656 \mathrm{c.}$

13. Тарле, Е. В. Крымская война / Е. В. Тарле.M. : ACT, 2005. $-1368 \mathrm{c}$.

14. Хомяков, А. С. Собрание сочинений / А. С. Хомяков. - Париж: YMCA-Press, 1989. - 714 c.

15. Шеремет, В. И. Крымскую войну начал Ватикан / В. И. Шеремет. - Электрон. текстовые дан. - Режим доступа: http://www.otechestvo.org.ua/main/20059/ 104 (дата обращения: 30.05.2016). - Загл. с экрана.

\section{REFERENCES}

1. Vakulova T.V. Konflikt tsivilizatsiy kak problema russkoy filosofii XIX-XX vekov [Conflict of Civilizations as a Problem of Russian Philosophy of the 19th-20th Centuries]. Uchenye zapiski Tavricheskogo natsionalnogo universiteta im. V.I. Vernadskogo. Seriya «Filosofiya. Sotsiologiya», 2008, vol. 21 (60), no. 3, pp. 249-260.

2. Vakulova T.V. Politologicheskiy analiz Krymskoy voyny cherez prizmu tsivilizatsionnoy teorii [Political Analysis of the Crimean War through the Prism of Civilizational Theory]. Gorod slavy $i$ pokloneniya: materialy nauch.-prakt. konf. [City of Glory and Worship: The Materials of ScientificPractical Conference]. Sevastopol, 2008, pp. 50-59.

3. Debidour A. Diplomaticheskaya istoriya Evropy. Svyashchennyy Soyuz ot Venskogo do Berlinskogo kongressa. 1814-1878. T. 1 [Diplomatic History of Europe. The Holy Alliance from the Vienna to the Berlin Congress. 1814-1878. Vol. 1]. Rostov-onDon, Feniks Publ., 1995. 508 p.

4. Dostoevskiy F.M. Paradoksalist [Paradoxer]. Russkie filosofy o voyne: F. M. Dostoevskiy, Vl. Solovyev, N. A. Berdyaev, S. N. Bulgakov, E. N. Trubetskoy, S. L. Frank, V. F. Ern [Russian Philosophers about the War: F.M. Dostoevsky, Vl. Solovyev, N.A. Berdyaev, S.N. Bulgakov, E.N. Trubetskoy, S.L. Frank, V.F. Ern]. Moscow, Kuchkovo pole Publ., 2005. 496 p.

5. Dubrovin N.F. Pervaya oborona Sevastopolya 1854-1855 gg. "Russkaya Troya»
[First Defence of Sevastopol in 1854-1855. The "Russian Troy"]. Moscow, Eksmo Publ.; Yauza Publ., 2014. 478 p.

6. Elavich B. Rossiya i oslozhneniya na Balkanakh. 1806-1914 [Russia and the Complications in the Balkans. 1806-1914]. Cambridge, Cambridge University Press, 1991. 292 p.

7. Potemkin V.P., ed. Istoriya diplomatii. Biblioteka vneshney politiki. $V 3 t$. [The History of Diplomacy. Library of Foreign Policy. In 3 vols]. Moscow, OGIZ Sotsekgiz Publ., 1941-1945. 1873 p. Available at: http://www. nnre.ru/istorija/tom_1_ istorija_diplomatii index.php. (accessed October $\overline{8}$, 2016).

8. Kiselev S.G. Osnovnoy instinkt tsivilizatsiy $i$ geopoliticheskie vyzovy Rossii [Basic Instinct of Civilizations and Geopolitical Challenges of Russia]. Moscow, Izvestiya Publ., 2002. 368 p.

9. Lenin V.I. «Krestyanskaya reforma» $\mathrm{i}$ proletarski-krestyanskaya revolyutsiya ["Peasant Reform" and Proletarian-Peasant Revolution]. Polnoe sobranie sochineniy: v 55 t. [The Complete Works: in 55 vols]. Moscow, Izd-vo polit. lit., 1973, vol. 20, p. 173.

10. Mify Krymskoy voyny [Myths of the Crimean War]. Available at: http://www.rne.org/sfk/0401/040116.shtml. (accessed May 30, 2016).

11. Selishchev N.Yu. Krymskaya voyna: mif ob otstaloy Rossii [The Crimean War: the Myth on Backward Russia]. Available at: http://rusk.ru/st.php? idar=318133. (accessed November 3, 2016).

12. Tatishchev S.S. Vneshnyaya politika imperatora Nikolaya Pervogo. Vvedenie v istoriyu vneshnikh snosheniy Rossii v epokhu Sevastopolskoy voyny [The Foreign Policy of Emperor Nicholas the First. Introduction to the History of External Relations of Russia in the Era of the Sevastopol War]. Saint Petersburg, Tip. I.N. Skorokhodova, 1887.656 p.

13. Tarle E.V. Krymskaya voyna [The Crimean War]. Moscow, AST Publ., 2005. 1368 p.

14. Khomyakov A.S. Sobranie sochineniy [The Collected Works]. Paris, YMCA-Press, 1989. 714 p.

15. Sheremet V.I. Krymskuyu voynu nachal Vatikan [Vatican Initiated the Crimean War]. Available at: http://www.otechestvo.org.ua/main/20059/104. (accessed May 30, 2016). 


\section{Information About the Author}

Tatyana V. Vakulova, Candidate of Sciences (Politics), Associate Professor, Department of Historical, Philosophical and Social Sciences, Sevastopol State University, Universitetskaya St., 33, 299053 Sevastopol, Republic of Crimea, Russian Federation, vakulo1@yandex.ru.

\section{Информация об авторе}

Татьяна Владимировна Вакулова, кандидат политических наук, доцент кафедры исторических, философских и социальных наук, Севастопольский государственный университет, ул. Университетская, 33, 299053 г. Севастополь, Республика Крым, Российская Федерация, vakulo1@yandex.ru. 